Georgetown University Law Center

Scholarship @ GEORGETOWN LAW

2017

\title{
In Praise of Richard Weisberg's Intransigence
}

Robin West

Georgetown Law, west@law.georgetown.edu

This paper can be downloaded free of charge from:

https://scholarship.law.georgetown.edu/facpub/1992

https://ssrn.com/abstract=3035406

\section{Law \& Literature 21}

This open-access article is brought to you by the Georgetown Law Library. Posted with permission of the author. Follow this and additional works at: https://scholarship.law.georgetown.edu/facpub 


\title{
In Praise of Richard Weisberg's Intransigence
}

DRAFT

\author{
Robin West
}

In early essays on Herman Melville's Billy Budd, Sailor, Richard Weisberg startled the literary and legal academic world with a novel claim: Captain Vere, he argued, far from being a tragic hero resigned to the moral and legal necessity of an unpopular act, as he had been commonly understood, was a murderer. ${ }^{1}$ His summary execution of Billy Budd for the killing of Claggart, Weisberg showed, was neither required, excused, nor justified by the Mutiny Act and the Laws of War under which Vere acted, and to which, as Captain of his wartime ship, he was bound. Acting as judge, juror, witness, prosecutor and defense counsel all, and arguing Budd's case in front of a tribunal consisting entirely of his own subordinates, Vere engineered an unreviewable conviction and death sentence, contrary to both the letter and spirit of the governing positive law. ${ }^{2}$ The trial, conviction and execution of Billy Budd were all unlawful. Vere was both morally responsible and legally culpable for Billy Budd's death.

Why was Weisberg's claim - that Captain Vere manipulated law and passion both, all so as to kill a popular sailor and for no good reason, much less out of moral or legal necessity - so novel, and even, as I want to suggest below, path-breaking? Not so much because of anything in the letter of Melville's story. Melville had provided sufficient evidence of Vere's mendacity and criminality both to sustain Weisberg's eventual verdict. ${ }^{3}$ Rather, I suggest, Weisberg's argument regarding the criminality of the commanding officer depicted in Billy Budd was such a surprise because of particular features of mid-to-late twentieth century intellectual thought, particularly in the legal academy, which taken jointly rendered Weisberg's legal interpretation of the law in Billy Budd - and the indictment not of Budd but of Captain Vere, which that interpretation implied - all but unthinkable. In retrospect,

${ }^{1}$ RICHARD WeISBERG, The Creative Use of Statutes for Subjective Ends: The Case of Billy Budd, Sailor, in FAILURE OF THE WORD (1984); Richard Weisberg, How Judges Speak: Some Lessons on Adjudication in Billy Budd, Sailor with and Application to Justice Rehnquist, 57 N.Y.U. L. REV. 1 (1982).

${ }^{2}$ WEISBERG, supra note 1.

${ }^{3}$ Weisberg lists several procedural irregularities in the trial, the most significant of which is that the law required Budd to be kept imprisoned, but alive, until such time as a court martial on land could be constituted to properly hear the case. WEISBERG, supra note 1 at 147. Several legal writers now concur with Weisberg that Vere's acts were unlawful. See, e.g., Daniel Solove, Melville's Billy Budd and Security in Times of Crisis, 26 CARDOZO L. REV. 2443 (2005), Lawrence Friedman, Law, Force, and Resistance to Disorder in Herman Melville's Billy Budd, 33 T. JEFFERSON L. REV. 61 (2001), Martha Umphrey, Comment on Jennifer Culbert's Shattering Law: Encounters with Love in Billy Budd, 28 QUINNIPAC L. REV. 781 (2010). 
thirty years later, I believe that its clear that Richard Weisberg's compelling interpretation of Billy Budd, Sailor - particularly when that interpretation is read in the context of his larger and later oeuvre on related themes - suggested a much needed corrective, not only of our understanding of Melville's story, but also of our conventional and critical jurisprudence. It suggested the case, more specifically, for moving both our conventional legal thinking away from its focus on the unjust law, and focusing instead on the duplicitous or unjust adjudicator, and for moving our critical sensibility away from its still-dominant commitments to indeterminacy, legal skepticism, and interpretive flexibility, and toward an appreciation of the virtues of legal intransigence. By so doing, Weisberg's claims about the nature of interpretation laid out a jurisprudential path not only for the law and literature movement, but for legal studies generally, characterized by very basic moral decency and intellectual integrity.

In this brief appreciation I won't re-litigate Weisberg's ultimate judgment on Vere; I think he's amply prosecuted his case, both in the original essays in which he put forward his claim and in his subsequent responses to critics. ${ }^{4}$ I would though like to show why the argument he gave and the conclusion he reached were so startling. Why was it, in short, that Weisberg's view of Vere as an anti-hero, rather than as a hero, was such an outlier? Put differently, why was it that for seven decades, well over half a century, Vere's villainy was so obscure, and more pointedly so obscure to so many legally sophisticated readers? To state my conclusion up front: I will ultimately argue that Vere's criminal mendacity has been obscure to most legal readers of the last seven decades largely because of the dominant jurisprudence, or legal theories, regarding the nature of law and interpretation of that time period - roughly the duration of the novel's existence. Weisberg's reading of Billy Budd and his understanding of Vere's character rest on a conception of law and legal meaning distinctively outside all of our received jurisprudential traditions. It is a reading of the novel, and a conception of law, from which we could all profit.

So, in the first part below, I will put forward an account of why it was that Richard Weisberg could see clearly what was beyond the reach to most of Billy Budd's professional readers for the duration of the book's life, both in law and in literature: that Melville's Vere, far from being a loyal wartime hero who sacrificed his own popularity and peace of mind in order to do the right and lawful thing, was actually homicidal; a murderous commander who invoked a hyped and self-serving emergency in order to dispense with accepted legal and procedural safeguards, his own moral compass, the dissenting voices of his compatriots, and Billy's life all. In the second part, I will turn to Weisberg's recent defense of legal intransigence, made implicitly in these early essays on Budd and explicitly in later work. In that section I will suggest some reasons we should attend more carefully than we have to date to the case Weisberg has made for intransigence and against "flexibility" in law and

\footnotetext{
${ }^{4}$ For a critical response, see Richard A. Posner, From Billy Budd to Buchenwald (reviewing Weisberg, Richard H., The Failure of the Word: The Protagonist as Lawyer in Modern Fiction (1984)), 96 YALE L. J. 1173 (1987). For Weisberg's response to Posner, see Richard Weisberg, Entering with a Vengeance: Posner on Law and Literature, 41 STAN. L. REV. 1597 (1989).
} 
jurisprudence - particularly when crafted as Vere-styled juridical responses to perceived emergencies - and whether the case for legal flexibility is propounded by military Commanders on ships of war, natural lawyers, critical legal scholars, Supreme Court Justices, or liberal legal devotees of judicial discretion, particularly in constitutional law. I will then offer a couple criticisms along with a qualified endorsement of Weisberg's brief for interpretive fidelity to positive law, informed by humane commitments to text, law, and moral rectitude.

\section{Richard Weisberg on Captain Vere}

I want to revisit Weisberg's argument from thirty five years ago regarding Billy Budd, and more specifically, the character of Captain Vere, highlighting features of it that have proven to be pivotal to his recent philosophical ambitions, but placing them, for these purposes, in the jurisprudential background against which he wrote. First, recall that Captain Vere, as a commanding officer on a ship of war, was faced with what appeared to be a straightforward albeit excruciating moral dilemma, familiar both to lawyers and literary readers since the time of Sophocles' Antigone: by killing Claggart, the popular sailor Billy Budd had unquestionably committed a capital offense, but seemed nevertheless morally innocent. Budd apparently lacked all criminal, much less homicidal intent; he simply was not deserving of the death sentence the Laws of War apparently prescribed. Vere fully recognized Budd's moral innocence, even referring to Budd at one point as an "Angel of God." 5 Thus, "natural law," or "moral law," or God's law, or simple human decency, all seemed to dictate the wisdom for some degree of leniency toward Budd: one should not, after all, kill innocents. The positive law, however, consisting of the Mutiny Act and the Laws of War, seemingly characterized the killing of a superior officer as both a strict liability and capital offense, thus proscribing the death penalty for what was basically an unintentional act, or at least, so Vere claimed. And what was Captain Vere's response to this dilemma? No M.L. King-ian civil disobedient he, Vere viewed his highest duty as obedience to the Crown, and hence to the positive law, not to the dictates of morality, God, common sense, decency, the popular will, or conscience. He viewed his duty, in other words, as running to the positive law, not to natural law. He had a moral obligation to obey and apply even a terribly unjust law - or a law that would be unjust as applied. Vere accordingly argued for and obtained a verdict of guilt and a sentence of death - all unreviewable - from his jury, which in turn consisted of officers below him in the chain of command.

How should the reader view Vere for this terrible decision - the decision to enforce a manifestly unjust law, at the expense of a sailor's life? Did Vere do the right thing? Very generally, we can identify three competing understandings of Billy Budd, each implying different conceptions of Vere and Vere's character, in the secondary literature on the story that focused at all on the law, and that were circulating in legal or literary academic circles, by the time Weisberg undertook his

${ }^{5}$ HeRman Melville, Billy Budd, Foretopman: What Befell Him in the Year of the Great Mutiny, in BARTLEBY THE SCRIVEnER, Benito CeRno, BILly Budd 236 (Quality Paperback Book Club ed. 1996) (1924) hereinafter "Billy Budd." 
study of the novella in the 1980s. On the first and most conventional view - and the view that likely dominated through the middle of the twentieth century - Billy Budd, and Melville himself, can be read as basically endorsing Vere's unpopular decision. It was necessary to preserve order, and therefore it was not only justified, but morally required. ${ }^{6}$ Vere's highest duty, after all, as a Commander on a Ship of War as well as an adjudicator, ran both to the law and to military order - not to God, natural law, or to individual conscience. As Vere himself suggested in his closing argument to his drumhead jury, his position was thus most unlike a judge acting under a landbased law, who may have recourse to doctrines of equity, which might ameliorate the harshness of a sentence, or a sentimental woman overly sensitive to the demands and niceties of sympathy. ${ }^{7} \mathrm{He}$, by contrast to both, did not have the luxury to succumb to the seductions of ordinary morality. As a responsible commander on a ship of war, he could not allow his construction of the positive law, which he was duty bound to uphold, to be tempered by the tug of sympathy or concerns for justice. ${ }^{8}$ His moral duty was to uphold the law, even in the face of a justice that would seemingly require him to repel it. Vere, then, most of Melville's professional readers concurred, was right to uphold the law and execute Billy, thus maintaining order and preventing mutiny. He was right to do so, furthermore, even in the face of justice, natural law, God's law, equity, equitable principles, common sense morality, the popular will, his own conscience, and the reservations of his hand-picked jurors - all of which, again as Vere himself acknowledged, seemed to dictate a different result.

Read this way, the story, along with this interpretation of it, stands in the post-war period as a quite depressing brief for the moral as well as practical necessity of order and obedience to hierarchical and particularly governmental commands, particularly in times of emergency, and the duty of those in positions of command to uphold discipline. That moral necessity for authority, discipline, obedience, and order imposes upon commanders, and leaders, a role-dictated duty to follow the positive law - a duty, in turn, to positive law which is only seemingly paradoxically "higher" than any duty to "higher" or natural law; it is a duty, in short, of politically empowered people to maintain the positive legal authority that in turn maintains order, even when unjust. Vere heard the clarion call of duty-to-law over justice, and should be commended for doing so. He was a tragic hero. More simply, he was a good man who did the right thing under trying circumstances. Thus - Billy $B u d d$, on this reading, is all about the moral necessity of law and order over justice, in case of conflict, and of a role-governed morality that calls upon those in charge to uphold it, even at the expense of their own conscience. Billy Budd Sailor, again on this conventional reading, is Melville's highly peculiar, even idiosyncratic, and

${ }^{6}$ See, e.g., Posner, supra note 4; Steven Wilf, The First Republican Revival: Virtue, Judging, and Rhetoric in the Early Republic, 32 CoNN. L. REV. 1675 (2000); Edwin M. Yoder, Jr., Fated Boy: Billy Budd and the Laws of War, 31 J. MAR. L. \& CoM. 615, 620 (2000).

${ }^{7}$ MELVILLE, supra note 5, at 67.

${ }^{8} \mathrm{Id}$. at 70 . 
decidedly anti-romantic ode to the virtue and necessity of strong political and legal authority, at least in times of national emergency.

The second possible interpretation is a sort of counter to this proauthoritarian interpretation. One could understand Vere, and presumably many of those high school and college students who read Billy Budd Sailor in their teenage years do read Vere, as having made the wrong choice, albeit for understandable, if not justifiable, reasons, as evidenced by the clear fact it is a choice which he later comes to deeply regret. Faced with a clear conflict between the dictates of the law and the dictates of justice - or between human and natural law - a commander should sometimes choose the latter, and perhaps even regardless of consequences, if the conflict is sufficiently grave. ${ }^{9}$ Law, after all, even in times of war, exists so as to serve justice, not the other way around, so if law in its application is thwarting justice, and one has the power to circumvent law without courting utter catastrophe, one should do so. Vere opted for positive law over natural law, and for order over justice, but he was wrong to do so, and for that he should be faulted. He should have disobeyed the law, the King, and the dictates of his role-dictated duty, if he had to, in order to follow the dictates of a higher moral law, or the dictates of conscience. Justice trumps law. The demands of order and political authority only go so far. Had he recognized this and acted accordingly, he would have been truly heroic. Vere failed this test of character, albeit, perhaps, for noble reasons: he was, after all, looking not only to uphold the law and the King's authority, but also to prevent a mutiny. He opted for peace over justice. But it was nevertheless a moral failure.

Although they are seemingly polar, note that both of these readings of Billy Budd - Vere as a noble commander who did the right thing by following the positive law although natural law and justice were seemingly against him, or Vere as having done the wrong thing in following the law, albeit for understandable reasons - rest on the same view of the governing law, and even of the relation of that law to morality, even as they differ in their assessment of Vere's decision and character. Both rest on the claim, or understanding, or assumption, that the positive law that bound Vere, and commanded Budd's execution, was both clear and unjust. Budd had admittedly killed a superior officer, which was defined as a strict liability offense under the Articles of War, and for which death was the proscribed penalty. The problem was that Budd was seemingly morally innocent. The two interpretations summarized above differ over the moral merits of Vere's resolution of the conflict he faced, but they rested on the same view of its nature: a just commander who earnestly tries to do his duty, when "doing one's duty" entails applying an unjust law. To follow the law is to offend justice, while to do the just thing requires acting contrary to law. Vere opted to follow the law, at the cost of justice. Perhaps he did so rightly, perhaps wrongly, but that was the conflict he

\footnotetext{
${ }^{9}$ See, e.g., Charles Reich, The Tragedy of Justice in Billy Budd, in Twentieth CENTURY InTERPRETATIONS OF BILly BudD (Howard P. Vincent ed., 1971). For discussions of the secondary literature, see WEISBERG, supra note 1, at 151, and Solove, supra note 3 , at 2245-46.
} 
faced. That conflict - the conflict between law and justice, between one's duty to law and one's moral duty - in other words, is what Melville's last novella is all about.

I will call both of these interpretations of Vere's dilemma, jointly, the "conventional account." I do not mean by doing so to minimize their differences: the norm underlying the former interpretation, if elaborated and particularly if it comes to define a stance toward the state, can veer toward an unpleasant authoritarian statism, while the norm underlying the latter can obviously lean toward an endorsement of an unacceptably anarchic and overly individualized mode of civil and judicial disobedience. The second understanding of Vere may be more pleasing to a post-civil rights and post-Vietnam War era generation, while the former, perhaps, may be more pleasing or at least more intelligible to that greatest generation who glimpsed the horrors of world-scale war. Nevertheless, both understandings share a completely conventional account of the law that generated the conflict. Both accounts share the view that the governing law was clear, that it clearly condemned Budd's act, and clearly supported Vere's decision to execute him. On the conventional account, no matter which way its resolved, the dilemma Melville's story dramatizes, is the moral quandary faced by a commander or a judge (rather than simply a citizen) who must obey or disobey - or apply, or refuse to apply - a manifestly unjust legal command.

In the early 1980s, this conventional account of Vere, and of Billy Budd, began to unravel, first in the literary academy, and then, eventually, in the legal. The first crack in the conventional legal-academic view of Vere, however, came not from Richard Weisberg, but from the renowned critical legal scholar and Yale Law Professor Robert Cover. In a short but thoughtful and influential aside in the preface of his masterful work Justice Accused, ${ }^{10}$ Cover offered an interpretation of Billy Budd Sailor, and of the governing law in Billy Budd, that was strikingly different from both of the conventional views recapitulated above, and that in turn heavily influenced Weisberg's reading a few years later. The conventional account of Vere's dilemma, Cover argued in Justice Accused, rested on a naïve view of the nature of the actual law in the novella, and perhaps a naïve view of law generally. The law maybe any law, but certainly including the Laws of War as presented by Vere - is indeterminate, Cover argued, its mandate was not, in fact, clear-cut. Those laws could be read so as to require Budd's execution, but other possible interpretations, more generous to Budd, were available, and would have been available to the bookish Vere, as both an astute reader of texts, including legal texts, and a sensitive commander. So, Cover argued, the premise of the conventional account was simply false: the presumably unjust law that generated the moral dilemma, was in point of fact not at all clear, so it can hardly be faulted for being unjust. The Laws of War that governed Budd's fate and Vere's dilemma did indeed present Vere with a choice but it was not the choice, as conventionally understood, between the "duty to faithfully apply the law" and the "duty to further justice," or a choice between obedience or disobedience. Rather, the indeterminacy of the Laws of War - again, perhaps the indeterminacy of law itself - presented Vere with an interpretive choice

${ }^{10}$ Robert M. Cover, Justice Accused: Antislavery AND the Judicial Process (1975). 
regarding how to understand the law's command. The power, then, that Vere wielded was not the severely constrained power to obey or disobey the governing law, but rather, the much more widely accepted - even by his own superiors power to interpret.

That interpretive power, in turn, gave Vere a degree of freedom, whether he wanted to acknowledge it or not. Vere had the choice, and hence the freedom, to interpret the law either generously, or not, against Budd. Yet, Vere consistently, repeatedly, denied he had that freedom and that choice, he consistently described the law governing his actions as clear and mandatory, unambiguous, and determinate. Vere's moral flaw, then, was pointedly and classically existential, or Sartrean; it was in his denial of his own freedom. The law presented him with an interpretive choice, and therefore a degree of freedom, which he consistently and adamantly denied he possessed. He did not have to kill Billy Budd, Cover urged, the law did not "make him" do it. The law did not in fact constrain his freedom. He did not have to disobey the law in order to save Budd's life. The law, as a text, precisely because of its indeterminacy, if anything, expanded Vere's power and freedom. Vere executed Billy Budd, and Vere chose to execute Billy Budd, and then he denied that that act was his own. He ascribed it, rather, and falsely, to law.

Now: on Weisberg. Cover wrote Justice Accused - a treatment of the interpretive choices faced by - and denied by - abolitionist judges in the prebellum period with respect to the Fugitive Slave Act, who Cover famously analogized to Captain Vere - in 1975.11 In his essays on Billy Budd that first appeared in law reviews in 1979, and which were later collected in his first book Failure of the Word, Weisberg referenced and praised Cover's critical reading of the law in $B B S$, and his existentialist critique of the bookish starry-eyed Vere. ${ }^{12}$ He then, however, provided his own quite distinctive interpretation, that also focused on the law, and Vere's relation to it, as had Cover, but that differed in quite profound ways as much from Cover's critical account, as from the conventional account that had preceded both of them. With Cover, Weisberg argued that Vere had grotesquely misstated the law, in order to wrongly justify his execution of Billy Budd. But contra Cover's account, Weisberg argued that the Law of War under which Vere acted was not in fact indeterminate, presenting Vere with an interpretive choice, although it was most assuredly complex and subtle. But, importantly, for Weisberg, it was not indeterminate. Nor, though, contra the conventionalist account, did the law support Vere's decision to execute the sentence without appellate review, and in fact quite the opposite. Rather, the law, Weisberg argued, clearly required procedural regularities that Vere ignored, all intended to protect against a rush to judgment in the face of a perceived emergency - precisely the situation on board the Bellipotent that Vere exploited. ${ }^{13}$ Had Vere followed the actual law rather than his own misstatement of it, he would have maintained the status quo on ship, holding Budd in place until a land court could have been convened, that would have then been required to conduct both a much fuller and a much fairer process. The Law of War -

${ }^{11}$ COVER, supra note 10, at 159-91.

12 WEISBERG, supra note 1 , at 142.

${ }^{13} \mathrm{Id}$. at 161. 
the law Vere wrongly claimed bound his hands and proscribed Budd's death - in fact required as much. Vere was wrong in his claim that the law required Budd's execution; in fact, that body of law forbade it. Vere acted, then, in contravention of a clear legal mandate, not in accordance with it.

Vere's mistake, however, was not innocent, and this is the heart of Weisberg's argument. Vere, Weisberg argued, was not mistaken about the law, rather, he misstated the law, and he did so intentionally. For psychic and professional reasons both, Vere needed a very public and even tragic but nevertheless legalistic triumph over adversity, and he used the law, a vague threat of mutiny, and Budd's lethal act, to engineer one. Thus, on Weisberg's reading, Vere executed a beloved sailor, and managed to accomplish the execution with no subsequent uprising, and he did it all in apparent accordance with law and duty and contrary to the dictates of the expressed sentiment of both his jurors and Budd's fellow sailors. He did it, though, in order to win acclaim and recognition by his peers and his superiors - not out of any felt or actual duty to apply the law, achieve justice, avert a mutiny, or maintain order, or express loyalty to the King. ${ }^{14} \mathrm{He}$ did it out of a thirst for personal aggrandizement.

The contrast with the conventional account is clear enough: Weisberg is the only theorist when he first wrote who argued for Vere's criminality rather than his heroism. Let me stress here, though, the difference with Cover's reading, which is considerably more subtle. Vere, on Weisberg's view, was not simply acting in bad faith, failing to see indeterminacy in a legal command, and hence a choice rather than a mandate. The problem Weisberg was stressing was not the one now familiar to us after years of indeterminacy critiques: that the law's indeterminacy permitted him a more generous interpretation than the one he wrongly believed mandated the harsh result. The problem the novella presents was not that Captain Vere believed himself bound where he in fact was not; that he could not or refused to see that his interpretation was a chosen one among possibilities. It wasn't that he was denying or blind to his own decisional freedom. Rather, the problem the novella presents is that Vere lied about the meaning of the law in a context in which he possessed the authority to render binding edicts, and he did so in order to achieve a personally desired end. His mendacity laid in his intentional abuse of his interpretative power. The problem was characterological, not existential.

The moral failing in Vere that his misreading and then misrepresentation of the law suggests, therefore, according to Weisberg, was interpretive disingenuity, not interpretive bad faith. Vere misled his shipmen, his jurors, Billy Budd himself, his peers, his superiors, and his subordinates, over the meaning of the law to which they all owed allegiance, and he did it in a way that served his own personal ends. Far from sacrificing conscience to the higher end of legal duty, therefore, Vere sacrificed legal duty, professionalism, justice, and positive and natural law both -- all for his own personal gain. He did it in the guise of legal duty, but the law which purportedly required him to do this unjust thing and to which he claimed allegiance was a perverted artifact of his own construction. The actual law was not unjust; nor

${ }^{14}$ Contrast Lawrence Friedman, who understands Vere's motivation as fear, rather than envy or jealousy. See Friedman, supra note 3, at 67. 
was it indeterminate or even particularly unclear. Vere was simply corrupt. The manifestation as well as the vehicle of his corruption was his perversion of the law.

Now, why was Weisberg's contrarian interpretation of $B B$ - that the positive law itself in Billy Budd Sailor was not the problem, that the law in fact was both relatively just and relatively clear, and that it was Vere - law's interpreter - who was unjust, and that he was unjust because of his departure from law, not from his cribbed allegiance to it - so novel, or surprising? Why didn't more readers, and particularly more legal readers, see in Melville's story at least the possibility that Vere misstated the law and that it was Vere, rather than the law, that was unjust? Well, maybe Weisberg was just wrong about the Laws of War and integrity of the text on this interpretation; Judge Posner for one argued as much. ${ }^{15}$ Without rearguing the point, in my view, Weisberg has successfully responded. ${ }^{16}$ A number of legally trained readers now concur. ${ }^{17}$

I want to suggest another hypothesis: at least one reason we have been so blind to Vere's misrepresentations of law in BBS, lies not in the text of BB itself, but rather, in the state of our twentieth century jurisprudence. The accounts of Vere given above, circa 1980 - Vere as noble commander forced to do an unpalatable act by virtue of duty, Vere as commander who lacked the wherewithal to resist an unjust law, or Vere as commander who failed to see or acknowledge his own interpretive power to read the law in a more generous way - are strikingly, and uncoincidentally, consistent with the major jurisprudential movements of the middle and the late twentieth century that then circulated in the legal academy. That jurisprudence constituted, in its totality, a massive shroud around Vere's mendacity. We couldn't see that mendacity, in short, because the various understandings of the nature of law then available to us obfuscated Vere's distinctive, and distinctively villainous, character. If Weisberg's claims about the novel are correct, then Vere exhibited a vice which was obscured, and badly, by twentieth century jurisprudence, in its entirety. It has similarly obscured the same of Vere's real world counterparts.

Let me start with the jurisprudence of mid-century, during which what I called the "conventional view" of Vere, and of Billy Budd, took hold. Law was regarded by most major theorists in the mid-twentieth century years as relatively determinate, knowable, clear, and as at least sometimes unjust. It therefore confronted adjudicators, at least from time to time, with moral dilemmas of just the sort Vere faced under the conventional account: whether to apply an unjust law, thus upholding the ideal of fidelity to law, or, instead, to refuse to apply it, doing an unlawful act so as to serve justice. Perhaps the central philosophical and moral issue posed by law, not only for citizens but more pointedly and in a quite different way for judges and commanders alike, during this time period, was what someone, such as a judge, should do, in the face of unjust laws. For some legal positivists, notably H.L.A. Hart, the possibility of a clear and clearly unjust law suggested in a fairly straightforward way that while judges for the most part may be duty bound to

\footnotetext{
${ }^{15}$ Posner, supra note 4.

${ }^{16}$ Weisberg, supra note 4, at 1182-84.

${ }^{17}$ See Umphrey, supra note 3; Solove, supra note 3; Friedman, supra note 3.
} 
apply the law as they find it, on occasion, a judge might indeed be morally justified in refusing, or even morally required to refuse, to apply a virulently unjust law - a judge, for example, facing a “Jewish law” in Vichy France or Hitler's Germany. ${ }^{18}$ For some natural lawyers, notably John Finnis and Lon Fuller, albeit in very different ways, a judge ought also generally apply the law, but again at least on occasion he or she might be not only justified but might be obligated to refuse to apply the unjust law, albeit on the more intellectually complex ground that a radically unjust law should not be understood as truly "lawful," or as having binding force. ${ }^{19}$ I'm not taking a position on this classical positivist-natural law debate. Whatever one's views on these questions, the dilemma discussed, and debated, by natural lawyers and positivists alike throughout much of the middle of the twentieth century was precisely the dilemma facing Vere under the conventionalist account described above: how a commander, or a judge, should act, or decide, in the face of a clear but unjust legal mandate. The problem of the unjust law, and the judge's relation to it, dominated jurisprudence. It could fairly be called, in fact, the central question of classical jurisprudence.

In the 1970s and 1980s, however, this conception of jurisprudence, and what is or isn't its central question, shifted. Both the liberal legal scholarship that dominated constitutional jurisprudence of the seventies and eighties, and then in a much more dramatic way the critical legal scholarship that captured the imagination of law's critics in the eighties and nineties, upended mid-century jurisprudential debates by denying the one premise that was shared by natural lawyers and positivists alike: that the law itself - at least sometimes, probably most of the time, and arguably all of the time - is in fact relatively clear, or determinate. Both liberal legalists and critical scholars, although in very different ways and toward different ends, denied just this assumption. Echoing, or indeed following, Robert Cover, a successive generations of liberal and critical scholars argued - or simply assumed that the law, contra the conventional view of mid-century, is much of the time or possibly always, radically indeterminate rather than clear. ${ }^{20}$ If that is right, then the central moral dilemma faced by a judge (or commander), or adjudicator, is not whether or not to refuse to apply an unjust law. Rather, the central moral dilemma faced by the adjudicator (whether judge or commander) is how to interpret, and then proclaim, an indeterminate law, and how to do so in the face of radically indeterminate legal materials, and, perhaps, whether the degree to which one's own freedom to pick one possible interpretation over another should be openly acknowledged. Liberal legal scholars and critical scholars have famously differed over their answers to these questions for the last forty years: for liberal legalists, the judge facing apparently indeterminate legal texts should resolve the indeterminacy

${ }^{18}$ H.L.A. HART, THE CONCEPT OF LAW 269 (2012).

${ }^{19}$ LON L. Fuller, The Morality OF LAW 54 (1964); JoHn FINNIS, NATURAL LAW AND NATURAL JUSTICE 273 (2011).

${ }^{20}$ See, e.g., Duncan Kennedy, Freedom \& Constraint in Adjudication: A Critical Phenomenology, 36 J. OF LEGAL EDUC. 518 (1986); Roberto Mangabeira Under, The Critical Legal Studies Movement, 96 HARV. L. REV. 561 (1983); MARK TUSHNET, RED White And Blue: A CritiCAl ANALysis of Constitutional LaW (1988). 
by reference to background moral principles drawn from law itself that render the text both determinate and just. For some, and particularly for Ronald Dworkin and the generation of constitutional lawyers that followed him on this, law should even be defined in such a way as to include those background moral principles. ${ }^{21}$ For critical scholars, following the legal realists from the early part of the century, a judge should forthrightly acknowledge the indeterminacy of law, and then resolve open questions in such a way as to promote his or her own view, all things considered, of wise social policy. Again, I don't mean to minimize these differences. But they share this common ground: for both liberal legalists and critical scholars, the central problem of jurisprudence is not the moral dilemma presented to a judge by virtue of an unjust law. Rather, the central jurisprudential dilemma - and hence the central question of jurisprudence, is, rather, the indeterminate law, and the central moral dilemma posed by that indeterminacy is not the unjust law, but the indeterminate one. For neither liberal nor critical scholars of the last quarter of the last century, has the duplicitous adjudicator, faced with relatively clear and relatively good law, but with personal motivations that might cloud judgment, appeared as the, or even a, central concern.

Thus, Weisberg's novel interpretation of Billy Budd - that the law was basically sound and that Vere's criminality was manifested in his intentionally perverse representation of the law - rested on a Weisbergian view of the moral perils of judging that went against the grain of our legal theory at least from the middle of the century through the 1990s, both conventional and critical, and possibly further back: recall that Oliver Wendell Holmes, the leading jurisprude of what Weisberg would now call "flexibility" in judging - famously opined that legal indeterminacy and policy-based judicial decision-making is not a cause for concern, basically because judges are, as a group, "wise and good men." 22 The badly motivated, duplicitous, criminal or untrustworthy adjudicator was just not much of a target of legal scholarship, or even of concern; the legal realists wanted judges to craft decent policy going forward, liberal legalists wanted judges to fairly apply moral principles to fill gaps in law, and critical theorists have famously espoused the necessity as well as virtue of overtly politicized judicial decision-making. None worried over the unjust adjudicator; all worried, instead, over the need to free the judge's hand to craft wise policy, from both the internal and external forces dictating a false legal necessity. Thus, putting this together, for the conventional legal theorists from mid-century, both natural lawyers and positivists, the focus of concern was the adjudicator faced with an unjust law, and for the liberal legal and critical theorist of the $80 \mathrm{~s}$ and $90 \mathrm{~s}$, the problematic adjudicator was the adjudicator who either failed to incorporate relevant moral principles into law or failed to acknowledge or didn't see law's indeterminacy, and thus didn't acknowledge his own freedom. The critic's focus was the adjudicator who acted in bad faith, rather than the adjudicator who manipulated law so as to achieve his own personal and duplicitous ends. Through the eighties and nineties, the formative years of law and

${ }^{21}$ RONALD DwORKIN, TAKING RightS SERIOUSLY (1978); RONALD DwORKIN, LAW'S EMPIRE (1986).

${ }^{22}$ Oliver Wendell Holmes, JR., The Common Law 137 (1881). 
humanities, Weisberg was essentially the only major legal theorist looking at the duplicitous and disingenuous adjudicator - the judge, lawyer, or military commander who misrepresented legal texts and then manipulated legal process toward his own personal ends, rather than the upright adjudicator faced with an unjust law or the adjudicator faced with unacknowledged indeterminacy. He found that ressentiment-driven and duplicitous adjudicator in Melville's Vere, but by no means only there: he found him in Chief Justice Rehnquist and his early opinions, ${ }^{23}$ in Justice Scalia's second amendment decisions, ${ }^{24}$ in a number of canonical works of fiction, ${ }^{25}$ and most importantly, in the writings of the early Christians, notably Paul and John's manipulative construction of Christianity on the basis of their intentional misreading of earlier religious texts. ${ }^{26}$ The wordy and educated man of law and letters can wield texts in ways intended to fulfill personal and perverse ends, and when he does so his erudite abilities and training become weapons of wanton destruction. Weisberg in effect introduced us to this character, in literature, in religion, and most persistently and most persuasively in law: the legally empowered man of texts and words, who abuses both to achieve his personal ends.

\section{Weisberg on Flexiphobia in Law and Literature}

Weisberg's condemnation of Vere, it should be recalled, rested on his manipulation of legal texts to achieve personal ends - not on the nature of the personal ends themselves. Ambition alone - what drove Vere - is hardly a vice. There's nothing terrible, or terrifying, about his jealousy of Admiral Nelson, or his desire to make a mark in his country's military history, or his desire to be recognized for it. Misstating the law so as to facilitate the execution of an innocent in order to further those ends, however, is. The ressentiment-driven, overly ambitious, bookish and careerist Vere, looking to achieve basically a PR victory for his own personal ends, manipulated the law so as to execute a morally innocent sailor, claiming to quell a likely nonexistent threat of mutiny. In his essays on $B B S$, Weisberg focused heavily on the character of Vere, and the mens rea, so to speak, of his crime: the frame of mind which drives a legally empowered person - a lawyer, judge, commander - to misstate or manipulate legal texts so as to achieve selfaggrandizing personal ends. In subsequent writing, however, and particularly in In Praise of Intransigence, Weisberg has focused far more on Vere's actual act, or actus res: the manipulation of texts, and the legal, social and cultural damage that manipulation of texts occasions. In the latter book, as well as in other recent writing, Weisberg isolates and specifices Vere's actus reus with greater particularity: the misstatement, by someone with legal authority, and in the guise of performing an act of legal "interpretation," of the relevant law, in order to achieve extraneous

${ }^{23}$ Weisberg, supra note 1.

${ }^{24}$ Richard Weisberg, In Praise of Intransigence: The Perils of FleXibility 143 (2014).

${ }^{25}$ WEISBERG, supra note 1 , at 170.

${ }^{26}$ WEISBERG, supra note 24 , at 82. 
and usually personal ends. That act is then masked by a cultural-legal stance toward law that permits or encourages "flexibility" in interpretation of texts, and it is that permissive stance, more than the particular acts, that is his ultimate target. In his book, Weisberg criticizes flexibility in all sorts of interpretive enterprises, not just the legal. In this context, however, I will refer to his target as interpretive legal flexibility. Let me review some of the harms of the flexibility in legal interpretation that Weisberg in my view correctly condemns, add just one, and then suggest some clarification of the basic thesis, which I believe is easily subject to misreading.

As with his claim regarding Vere's villainy, however, the first thing to note regarding Weisberg's condemnation of interpretive legal flexibility - and, on the flip side, his praise of "flexiphobia," which I will re-label "interpretive intransigence" - is its extraordinary oddity. It is quite an understatement to note that virtually any critique of interpretive flexibility in law goes against the grain of what is now fully conventional, post-legal realist, academic and juridical jurisprudential thinking. The praise of intransigence and the condemnation of flexibility both seemingly support precisely the stubbornness, rigidity, and hidebound, reflexive, precedent-bound legal traditionalism which Oliver Wendell Holmes famously found so odious in too many of his peers on the Bench: there is no worse reason to decide a case in a particular way, Holmes opined, than that it was so decided in the time of Henry the IV. ${ }^{27}$ Judge Posner echoes the sentiment nearly a hundred years later: flexiphobia is the heart of the "legal formalism" that Posner and an entire generation of likeminded legal pragmatists have routinely condemned, both in judges and academics: the belief, grounded in superstition or childishness, that judges should decide cases primarily or exclusively by reference to pre-existing law, rather than by flexibly employing the law to defend conclusions reached on forward looking, pragmatic, and generally utilitarian grounds. ${ }^{28}$ That "formalist" reliance on existing law, faithfully applied, rather than forward looking policy, as the better and indeed the only truly legal grounds for judicial decision making has been the target of legal realists, critical legal scholars, and (for different reasons) liberal legalists and legal economists now for a hundred years; indeed, their shared contempt of formalism is the only ground these otherwise disparate jurisprudential approaches to law share. What Weisberg embraces - intransigence - is what is near-universally condemned or ridiculed as on the ashbin of history, and what he dubs and then damns as flexibility, in law, is what is now almost universally regarded as enlightened, forward-looking judicial thought.

Why this broad consensus? Obviously, or so its thought, intransigence in law risks all of the perceived sins of bullheadedness for which its ridiculed in life generally. Law, furthermore, by its nature, is already inescapably conservative - it seeks to preserve some aspect of the social world against change simply by subjecting it to rule. Perhaps in part for that reason, legal flexibility, not intransigence, is the well-understood path of the law for our common-law governed fields: law, which seeks to preserve, must also evolve, and flexibility seems like the best stance to facilitate that evolution. So - our common law of tort, contract,

${ }^{27}$ Oliver Wendell Holmes, Jr., The Path of the Law, 10 HARV. L. REV. 457 (1897).

${ }^{28}$ Richard PoSNER, LAW, PRAGMATISM, AND DEMOCRACY 84 (2005). 
property and the principles that govern them have grown, shrunk, and changed, to accommodate the needs of industry, agriculture, commerce and technology. They all have proven sufficiently flexible to respond to changing political and economic pressures, without the constant need for legislative revisions. More profoundly, constitutional law, at least in the United States, has evolved, the efforts of originalists notwithstanding, to meet the changing mores and fundamental values of the people whose law it governs, and it has done so, generally, in a progressive and morally sound direction. Without flexibility, we would never have had Brown v Board of Education ${ }^{29}$ or Roe $v$ Wade: ${ }^{30}$ the Constitution says nothing of segregated schools or rights to abortion. Only by reading the Constitution flexibly, could we achieve these great gains in our civil rights of equality and liberty. For these reasons and a host of others, we teach the virtue of legal flexibility, so to speak, reflexively in law school classes: common law rules develop by absorbing by analogy new fact patterns, and through the process, facilitating the articulation of new concepts, which grow from but which are by no means bound by their origin. Intransigence is little more than a thorn in the side of a forward-looking judiciary respectful of but not constrained by historical precedent. In a post realist world, it is virtually the antithesis of the judicious temperament. Given all of this, why would anyone praise intransigence? Why does Weisberg?

Weisberg puts forward a number of arguments against flexibility generally, which I won't touch on here, but he also asserts two very general arguments against legal flexibility, both of which are implied in his early writing on Billy Budd and his analysis of Vere. I will grossly simplify them here, and then offer a comment. First, the valorization of legal flexibility which we have, as an academy, engaged, from the time of the legal realists to the present, masks precisely the kinds of legal malfeasance that Vere represents - the ressentiment-driven man of words, books, and letters, who is empowered by law, and who, for deeply personal and psychological reasons, is envious and resentful of natural strength, beauty, life, force, and power. ${ }^{31}$ With interpretive flexibility, and even more so with the boundless indeterminacy championed by critical scholars, comes less - not more ground for addressing, or even claiming, the wrongness of this kind of lethal manipulativeness. Yes, it is certainly true that the judge facing indeterminate law cannot claim to be constrained by it - Vere's decision, as Cover pointed out, was his, not "the law's." If we assume legal indeterminacy, then Vere and others in his position are deprived of the excuse, so to speak, that "the law made me do it." But, at the same time, the judge who has and who is assumed to have only indeterminate legal materials at hand is freed of all responsibility for fidelity. He cannot possibly have an obligation to follow the law, if the law provides no determinate guidance. Now of course, this unquestionably does happen from time to time, simply given the nature of rules and language: as H. L. A. Hart argued, judges who must decide cases in the gray or penumbral area of legal uncertainty must act to some degree essentially as a legislator. But if we simply presume that all law is by its nature

${ }^{29}$ Brown v. Board of Ed. Of Topeka, Shawnee County, Kan. 347 U.S. 483 (1954).

${ }^{30}$ Roe v. Wade, 410 U.S. 113 (1973).

31 WEISBERG, supra note 24. 
indeterminate - that all law is essentially in the gray area -- and that flexibility is a judicial virtue, rather than an occasional necessity, then the unmoored judge becomes the norm - indeterminate law requires essentially nothing of him. He can be, and should be, flexible: he can respond to changing circumstances, he can be "pragmatic," he can weigh costs and benefits, he can apply moral principles, he can do the best thing all things considered. He can also, however, be unhinged, as was Vere. If we assume the necessity and the universality of the untethered judge, because we assume the invariability of legal indeterminacy, then we will mask, to some degree, the potential venality of that most unjudicious judicial character. Thus, the first cost of flexiphilia: we will not recognize the Captain Veres in our legal world, whether they are on the Supreme Court or lower courts, because we will come to see their peculiar form of verbal manipulativeness as the norm. This is no small matter. Law is precisely the institution, and the profession, that should ideally, and minimally, constrain political perversion and abuse of power, and it should do so through the affirmative but confining powers of words. If we adopt a stance toward its interpretation that robs us of the linguistic capacity to do so, we will have stripped the institution of law of its moral purpose and capacities.

The second claim is more subtle, and also, I think, considerably more problematic. Weisberg's flexiphobia - his praise of intransigence - urges on us a faith, not only in cultural texts, but also, basically, in law, at least as a kind of baseline, or presumption. Faith in law, in turn, is grounded in the larger Weisbergian faith in texts, language, and the binding powers of words, at least when they are interpreted in a way that accords weight to fidelity. ${ }^{32}$ But the same vehicle - words - become the weapon of the resentful, erudite, destructive Vere; words, then, are the quintessential double edged swords. When words fail to bind us perhaps because of dishonesty, but perhaps more pervasively because of our love of flexibility, or what might be called our flexiphilia - then law fails to bind us, which, Weisberg argues, might be liberating on occasion but will far likely prove to be calamitous. ${ }^{33}$ When the word loses its binding power - when we are faced with a "Failure of the Word," as he titled his first and most important book, then law's claim to being a moral constraint on psychic perversion and political harm disappears. It becomes that which it would otherwise constrain; a vehicle for the abuse of both the weak by the strong, but also of the naturally strong by the weak: the weak, this time, that somehow attains legal power, and whose weakness is then strengthened by the hand of erudition and legal empowerment, put to perverse ends.

Best understood, both the power and the virtue of law come not from the point of the sword, but from the binding power of the Word - it is when law is expressed through words that communicate that it has some essential and redemptive connection toward equality and community both. Our faith in law is rational, then, when it is a faith in law's words: it is the Word that can morally constrain us, but it only does so if we can morally interpret it - by so doing, we use it to build as well as facilitate equalizing connections among us. When we lose our

${ }^{32} I d$.

${ }^{33} I d$. at 13; WEISBERG, supra note 1, at 159. 
capacity to interpret the Word, and our understanding of that capacity, we lose, basically, law's institutional capacity to morally constrain us against our own psychic perversions. I'd call the Weisbergian jurisprudential stance, therefore, not so much a faith in Law, as a faith in Law's Word, honestly rendered. Weisberg's argument, in its essence, is that faith in law is only justified if and when it rests on a faith in Law's Word, and that the latter depends entirely and with great fragility on a capacity for honest and indeed inflexible interpretation.

Weisberg's faith in Law's Word is not bottomless, naïve, or unqualified although it might initially so appear. Infidelity to the Word, including to Law's words, can be calamitous, and therefore, interpretive flexibility can accommodate and mask - moral disaster, up to and most assuredly including genocide. That is Weisberg's basic brief. On the other hand, Law's words - including Law's original texts - are not necessarily the heart of virtue, and Weisberg recognizes this: he condemns in no equivocal or uncertain language apartheid regimes, such as the US pre-bellum South, ${ }^{34}$ the denial of basic political rights for women in pre-19th Amendment America, ${ }^{35}$ the Jewish laws of Vichy France during the rise of fascist Europe, ${ }^{36}$ and of course the genocidal Jewish laws of the Third Reich. ${ }^{37}$ All of these systems of oppression were grounded in law, and its texts and words. Weisberg well recognizes the danger of legalized evil, including legalized genocide. He recognizes likewise the danger of unthinking obedience to law, even when scrupulously interpreted with utmost fidelity. He recognizes, in other words, that the dangerousness of law lies not only in the license that a stance of interpretive flexibility lends to the Captain Veres among us, but also in a stance of unreflective obedience to it, when the Word that is its original text is malign. Nevertheless, the possibility of malignant law does not undercut the dangers of flexible interpretation. Richard Weisberg's distinctive sensitivity, and the immense added value of his writing to the jurisprudential canon, lies not in his recognition of law's evil, but rather in his recognition of law's goodness, and of the dangers of infidelity toward it, particularly when harbored by law's custodians and guardians. That sensitivity, in turn, is grounded not only in a healthy skepticism toward Vere and his ilk, but also in a healthy appreciation of law's value, in the hands of upright stewards.

Finally, my two qualifications, or clarifications. First, as suggested above, its worth clarifying that Weisberg's endorsement of interpretive intransigence is not simply an endorsement of law - a sort of "law is law" version of legal positivism, combined with an unyielding duty of obedience. It's not clear that any legal positivist holds such a view, but it is certain that Weisberg does not. He well recognizes both the reality and the possibility of unjust law - of law that a citizen or judge both might have not just a right but even a moral duty to disobey. What Weisbergian intransigence does insist on, however, is intransigence in the act and process of interpretation - of declaring the law - not blind obedience to it. Nothing

${ }^{34}$ See Richard Weisberg, Review: In Search of Faulkner's Law, 92 MiCH. L. REV. 1776, 1778 (1994).

${ }^{35}$ WEISBERG, supra note 24, at 129.

${ }^{36}$ Richard H. WEISBERG, Vichy LAW AND THE HOLOCAUST IN FRANCE (1998).

${ }^{37} \mathrm{Id}$. 
follows at all, regarding a duty of obedience, from a duty of intransigent interpretation. In fact, although Weisberg doesn't elaborate the argument, one virtue of the intransigent interpretation he's calling for is that it makes clear, just as flexible interpretation obfuscates, the need for disobedience, both of citizens and judges - when immoral laws demand it. Sometimes a deep and intransigent understanding of law - or Constitutions - yields a morally good result that for whatever reason is not readily apparent from text. Weisberg may be right that Brown v. Board is such a case. But sometimes, and Weisberg's own faith in the US Constitution notwithstanding, the deepest and most faithful and most intransigent understanding of law yields a result so repugnant to morality or justice that a judge is truly faced with the conflict that Vere falsely claimed: an irresolvable conflict between the dictates of law and the requirements of justice. Nothing in Weisberg's faith in Law's Word suggests that these conflicts will not occur, and that at times that they will not be devastating. When a judge is faced with such a conflict, he or she might decide to disobey - engage in an act of judicial disobedience - or step down. But it is an attitude of interpretive intransigence - not interpretive flexibility - that will isolate and clarify these conflicts.

Second, Weisberg sometimes labels his own position an endorsement of intransigence (which I've re-labeled above "interpretive intransigence") and in other places, more pithily, "flexiphobia." I prefer the former formulation, because it references what he's for rather than what he's against, but there's nevertheless an important insight in the more negative word he's coined. It may be that what we should embrace, at least with respect to legal interpretation, is not so much intransigence itself as an attitude: a skeptical stance toward interpretive claims that turn out to depend upon or be rooted in nothing but the purported virtue of flexibility. We should be most skeptical of claims in defense of far-fetched adjudicative positions rooted in the claimed necessity of flexibility. But skepticism toward either the wisdom or necessity of flexibility in interpretation is not the same thing as intransigence. So, while the book is titled "In Praise of Intransigence," that is not quite what the book does. What it does, at least more consistently, is praise a stance of skepticism toward claims based on the value or necessity of interpretive freedom. Similarly, Weisberg consistently labels the target of his critique "flexibility." Here too, though, I think the better target is a stance, or an attitude, not flexibility itself. We could call the position he's targeting, for the sake of parallelism, "flexiphilia." Flexibility, after all, is often called for. Arguably, we couldn't survive without it. Flexibility itself is not evil, not even flexibility toward sacred or deeply cherished texts. Flexiphilia, though, is different; it is an attitudinal predisposition that assumes the necessity or virtue of flexibility in any and all circumstances. It is that attitude transported into the legal context - the claim that legal texts can mean anything or nothing, and therefore don't really mean anything at all - that robs the Legal Word, and therefore legal texts, and therefore law, of all morally redemptive authority.

It is also that attitude - an attitudinal predisposition toward the claimed necessity or virtue (or both) of flexible interpretation, all in defense of preposterous decisions purportedly based in texts - and not flexibility per se - that has been Richard Weisberg's target throughout his career. Vere executes an innocent sailor 
and falsely claims authority by referencing a flexible interpretation of the Articles of War. Saints John and Paul claim the foundation of a new religion in perverse interpretations of sacred religious texts. Bush Administration lawyers claim authority for torture by referencing loose interpretations of the Geneva Conventions. Justice Scalia does likewise with respect to the Second Amendment and the Right to Bear Arms. All of these actions are taken either in part or whole by claiming authority for them in flexible interpretations of preexisting texts, rendered by legally empowered actors responsible for preserving just those texts. Those flexible interpretations, then, in turn, either justify or excuse or necessitate otherwise pernicious actions. The actor then has the imprimatur and the additional fire power of some form of law. The rest of us, when faced with the torture, or the unreviewable execution of an innocent at sea, or the Jesus movement, or a dangerously armed citizenry - are to some considerable degree incapacitated even from criticizing these acts, in part by our now-widespread twentieth and twentyfirst century insistence that flexibility in legal interpretation is either a virtue or a necessity, or quite possibly both. These actions, that is, are furthered, because legitimated, by our flexiphilia.

Flexiphilia is neither a left nor right wing version of legalism, it is not clearly aligned with either natural law or positivism. It is a pervasive feature of modern legal thought, reflected not only in Posnerian pragmatism and Holmesian realism, but also in the economic analysis of law, in critical scholars' penchant for indeterminacy, and in liberal legalism's embrace, from Brown and Roe forward, of principle and policy, rather than law and text, as the better guide for judicial discretion. It has been Richard Weisberg's life work to identify the shared ground flexiphilia - of these radically disparate positions - to alert us to the moral and indeed existential danger in that stance, and to call us out on it. He has issued this warning persuasively, eloquently, critically, and graciously. It would behoove us to take heed. 